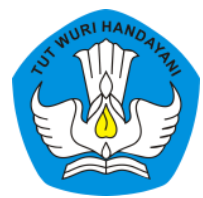

Page: 507-522

\title{
PENGARUH MODEL TWO STAY TWO STRAY TERHADAP HASIL BELAJAR MATEMATIKA SISWA KELAS II SD
}

\author{
Wahyul Huda \\ Sekolah Dasar 1 Barongan, Kudus, Jawa Tengah, Indonesia \\ Contributor Email: wahyulhuda1987@gmail.com
}

Received: Feb 14, 2021

Accepted: Jun 9, 2021

Published: Jul 30, 2021

Article Url: https://ojsdikdas.kemdikbud.go.id/index.php/didaktika/article/view/319

\begin{abstract}
This research aims to determine the influence of Two Stay Two Stray models on the results of the mathematics learning material to build a class II student in SD 1 Barongan, Kudus District. This type of research is quasi-experimental with the form of Nonequalivalent control group design. The samples on this study were by using saturated sampling because of the relatively few population counts. The results of $N$ gain analysis shows that conventional learning models in the control class gained 0.29 with less criteria while the experimental class with the implementation of the Two Stay Two Stray Learning model received 0.39 with moderate criteria. The ttest results show that $t_{\text {value }}$ is 2.104 while $t_{\text {table }}$ is 2.001 or $t_{\text {value }}>t_{\text {table }}$ and the significance of it is 0.000 so $\mathrm{HO}$ is rejected. The linear regression test of Two Stay Two Stray models on the student's mathematical learning results of a $89.3 \%$ space build. The conclusion of the study was (1) there were differences in the learning outcomes of the space between students in the control class without the implementation of the Two Stay Two Stray Learning model and the experimental class with the adoption of the Two Stay Two Stray Learning model, (2) there was a significant influence on the material's learning to build space on the experimental class with the adoption of the Two Stay.
\end{abstract}

Keywords: Two Stay Two Stray Model; Learning Outcomes; Mathematics 


\begin{abstract}
Abstrak
Penelitian ini bertujuan untuk mengetahui pengaruh model Two Stay Two Stray terhadap hasil belajar matematika materi bangun ruang siswa kelas II SD 1 Barongan Kabupaten Kudus. Jenis penelitian ini adalah quasi-experimental dengan bentuk nonequalivalent control group design. Sampel pada penelitian diambil dengan menggunakan sampling jenuh karena jumlah populasi relatif sedikit. Hasil analisis n-gain menunjukkan bahwa model pembelajaran konvensional pada kelas kontrol memperoleh 0,29 dengan kriteria kurang sedangkan kelas eksperimen dengan penerapan model pembelajaran Two Stay Two Stray mendapatkan 0,39 dengan kriteria sedang. Hasil Uji t menunjukkan nilai thitung = 2,104 sedangkan $t_{\text {tabel }}=2,001$ atau $t_{\text {hitung }}>t_{\text {tabel }}$ dan signifikansinya sebesar 0,040 sehingga HO ditolak. Uji regresi linear model pembelajaran Two Stay Two Stray terhadap hasil belajar matematika siswa materi bangun ruang sebesar 89,3\%. Simpulan dari penelitian ini adalah (1) terdapat perbedaan hasil belajar materi bangun ruang antara siswa pada kelas kontrol tanpa penerapan model pembelajaran Two Stay Two Stray dan kelas eksperimen dengan penerapan model pembelajaran Two Stay Two Stray, (2) terdapat pengaruh yang signifikan hasil belajar materi bangun ruang pada kelas eksperimen dengan penerapan model pembelajaran Two Stay Two Stray.
\end{abstract}

Kata Kunci: Model Two Stay Two Stray; Hasil Belajar; Matematika

\title{
A. Pendahuluan
}

Matematika merupakan salah satu mata pelajaran yang cukup vital bagi siswa sebab Matematika akan membekali kemampuan berhitung yang sangat dibutuhkan siswa dalam melanjutkan ke jenjang pendidikan berikutnya maupun dalam kehidupan sehari-hari. Tidak jarang siswa merasa kurang mampu dalam mempelajari matematika sebab matematika dianggap sulit, menakutkan. Bahkan, sebagian dari mereka ada yang membencinya sehingga matematika dianggap sebagai momok. Ketakutan yang muncul dari dalam diri siswa tidak hanya disebabkan oleh siswa itu sendiri, tetapi juga didukung oleh ketidakmampuan guru menciptakan situasi yang membawa siswa tertarik pada matematika. Selain itu, siswa yang berprestasi rendah cenderung tidak menyampaikan pertanyaan atau jawaban dalam upaya menghindari umpan balik negatif dan mendapat malu di kelas.

Siswa terbiasa menerima informasi yang disampaikan oleh guru tanpa mepahami terlebih dahulu. Metode yang digunakan oleh siswa dalam belajar 
adalah menghafal (Abtahi \& Battell, 2017). Jadi, guru menyampaikan informasi dan siswa hanya menghafal serta menelan mentah-mentah informasi tersebut tanpa memahami terlebih dahulu. Siswa dapat memahami contoh soal yang disampaikan oleh guru di papan tulis, tetapi ketika diberi soal yang berbeda siswa tidak dapat mengerjakan soal tersebut. Kondisi yang demikian membuat siswa menjadi bosan dan kurang tertarik pada pembelajaran. Pembelajaran yang menggunakan model konvensional menyebabkan hasil belajar tidak tercapai secara maksimal karena tidak berlangsung secara efektif.

Faktor lain yang menjadi hambatan pembelajaran matematika yaitu tingkat kemampuan dan kecerdasan siswa yang beraneka ragam (Vitoria \& Monawati, 2016). Hal ini menuntut siswa untuk belajar lebih giat daripada siswa yang sudah memiliki kemampuan di atas rata-rata. Beberapa siswa juga beranggapan bahwa matematika merupakan mata pelajaran yang menakutkan, membosankan, dan cenderung tidak menyenangkan dibandingkan mata pelajaran yang lain. Hal ini menyebabkan aktivitas belajar siswa menjadi rendah, baik aktivitas fisik maupun mental (Fonna \& Mursalin, 2018). Akibatnya, hasil belajar matematika mereka kurang maksimal.

Peneliti mendapatkan gambaran awal dari hasil nilai ulangan harian tema 3 pembelajaran matematika pada kelas II tahun pelajaran 2019/2020 masih tergolong rendah. Kriteria Ketuntasan Minimal (KKM) untuk mata pelajaran matematika adalah 70. Jumlah siswa kelas II SD 1 Barongan yaitu sebanyak 61 orang. Terdapat 35 orang siswa yang nilainya belum mencapai Kriteria Ketuntasan Minimal (KKM) atau 57\%. Berdasarkan nilai yang diperoleh, dapat disimpulkan bahwa siswa masih memiliki kemampuan yang rendah dalam pembelajaran matematika. Hal ini dikarenakan guru belum menerapkan model pembelajaran yang tepat sehingga aktivitas dan hasil belajarnya pun rendah.

Berdasarkan permasalahan di atas perlu adanya alternatif pemecahan masalah yaitu dengan menciptakan pembelajaran yang efektif. Pembelajaran efektif dapat tercapai dengan cara menciptakan suasana kelas yang menyenangkan sehingga siswa mendapatkan 
kesempatan untuk berinteraksi satu sama lain (Hamruni, 2012: 29). Pembelajaran yang menyenangkan dapat terlaksana apabila siswa terbebas dari rasa takut dan ketegangan. Suasana yang demikian dapat mengembangkan seluruh potensi yang dimiliki siswa.

Siswa pada jenjang sekolah dasar memiliki karakteristik senang bermain, bergerak, bekerja dalam kelompok, dan melakukan sesuatu secara langsung. Guru perlu mengembangkan pembelajaran yang mengandung unsur permainan dan mengusahakan siswa berpindah atau bergerak. Belajar dalam kelompok dapat memberikan kesempatan bagi siswa untuk terlibat langsung dalam pembelajaran (Desmita, 2014: 35).

Salah satu model pembelajaran yang menjadi alternatif pemecahan masalah pada mata pelajaran matematika yaitu model pembelajaran Two Stay Two Stray (TSTS). Model pembelajaran ini dilaksanakan dengan cara berbagi pengetahuan dan pengalaman dengan kelompok lain. Selain itu, keterlibatan dalam kelompok dapat menunjang aktivitas belajar siswa melalui interaksi saling mengingatkan kinerja perseorangan untuk memastikan bahwa semua anggota kelompok berkontribusi dan belajar (Arthaningsih dan Diputra, 2019). Hal ini sejalan dengan penelitian Bagas, dkk. (2018) yang menemukan bahwa penerapan pembelajaran kooperatif tipe TSTS mampu meningkatkan kemampuan pemecahan masalah matematika siswa kelas VIII-G SMP Negeri 1 Surakarta tahun pelajaran 2016/2017 pada materi geometri.

Peneliti memilih model pembelajaran Two Stay Two Stray dengan alasan prosedur dalam model pembelajaran tersebut dapat mengaktifkan siswa dalam pembelajaran. Setiap siswa mempunyai tanggung jawab untuk menyelesaikan tugas masing-masing meskipun dilaksanakan secara berkelompok. Model pembelajaran Two Stay Two Stray dapat meningkatkan keterampilan bersosial karena setiap siswa berinteraksi dengan berkunjung ke kelompok yang lain ataupun menerima tamu dari kelompok lain.

\section{B. Metode}


Penelitian ini termasuk penelitian quasi-experimental dengan bentuk nonequalivalent control group design. Variabel bebas dalam penelitian adalah penerapan model pembelajaran Two Stay Two Stray sedangkan variabel terikatnya adalah hasil belajar matematika siswa kelas II SD.

Populasi dalam penelitian ini adalah siswa kelas II SD 1 Barongan Kabupaten Kudus yang berjumlah 61 orang siswa, terdiri dari 30 orang siswa kelas 2A dan 31 orang siswa kelas 2B. Sampel pada penelitian ini ditetapkan dengan menggunakan sampling jenuh karena jumlah populasi relatif sedikit. Selain itu, peneliti ingin membuat generalisasi dengan kesalahan yang sangat kecil. Hal ini diperkuat dengan pendapat Musfiqon (2012: 91) yang mengemukakan apabila jumlah populasi kurang dari 100 orang maka semua orang sebaiknya diteliti. Kelas yang dijadikan kelas eksperimen dan kontrol ditentukan berdasarkan hasil undian. Hasil undian menunjukkan bahwa kelas 2A terpilih sebagai kelas kontrol dan 2B sebagai kelas eksperimen.

Kelompok eksperimen dan kelompok kontrol sebelum diteliti mendapatkan perlakuan yang sama yaitu mendapat tes awal untuk mengetahui kesamaan rata-rata. Peneliti melaksanakan pembelajaran dengan model yang berbeda, yaitu pada kelas eksperimen diberi perlakuan dengan menggunakan model pembelajaran Two Stay Two Stray, sedangkan di kelas kontrol tidak diberi perlakuan akan tetapi menggunakan model pembelajaran konvensional.

Uji analisis yang dilakukan yaitu analisis instrumen dan analisis data. Analisis instrumen meliputi uji validitas dan reliabilitas. Metode analisis data terdiri atas analisis data awal dan akhir. Analisis data awal meliputi uji normalitas dan uji homogenitas. Analisis data akhir mencakup gains skor, uji-t dan uji regresi linear.

\section{Hasil dan Pembahasan}

\section{Hasil}


Data hasil belajar siswa kelas II materi bangun ruang diperoleh dari pretest dan posttest. Skor pretest dan posttest siswa kelas eksperimen dan kelas kontrol ditampilkan dalam Tabel 1 berikut.

Tabel 1: Skor Pretest dan Posttest Siswa Kelas Eksperimen dan Kelas Kontrol

\begin{tabular}{lcccccccc}
\hline Data & Kls & N & Skor Ideal & $\begin{array}{c}\text { Skor } \\
\text { Min }\end{array}$ & $\begin{array}{c}\text { Skor } \\
\text { Max }\end{array}$ & Rata-rata P (\%) & Ket \\
\hline Pretest & K & 30 & 100 & 40 & 70 & 55,33 & 55 & C \\
& E & 31 & 100 & 40 & 80 & 60,65 & 61 & C \\
Posttest & K & 30 & 100 & 50 & 90 & 68,33 & 68 & C \\
& E & 31 & 100 & 50 & 100 & 76,12 & 76 & B \\
\hline
\end{tabular}

Dari Tabel 1 dapat diketahui bahwa rata-rata skor pretest hasil belajar kelas eksperimen 60,65 sedangkan kelas kontrol 54,66 yang keduanya termasuk pada kategori sedang. Skor meningkat setelah dilakukan pembelajaran, rata-rata skor yang dicapai siswa kelas eksperimen 76,12 sedangkan kelas kontrol 70,33. Kelas yang mendapat skor lebih tinggi adalah kelas yang menggunakan model pembelajaran Two Stay Two Stray.

Sebelum pembelajaran menggunakan model pembelajaran Two Stay Two Stray dilakukan, hasil belajar materi bangun ruang siswa dari dua kelas yang diteliti masuk dalam kategori C (sedang). Setelah dilakukan pembelajaran menggunakan model pembelajaran Two Stay Two Stray, tingkat hasil belajar materi bangun ruang siswa pada kelas eksperimen mencapai kategori B (tinggi), dan kelas kontrol masih dalam kategori C (sedang).

Uji perbedaan 2 rerata secara statistika dilakukan untuk mengetahui perbedaan skor pretest dan posttest antara 2 kelas yang diteliti. Pada posttest telah dilakukan uji normalitas dan uji homogenitas semua berdistribusi normal. Selanjutnya, untuk mengetahui selisih antara nilai pretest dan posttest maka dilanjutkan uji gain.

Uji gain score dilakukan untuk mengetahui selisih antara nilai pretest dan posttest. Uji gain dilakukan setelah semua uji prasyarat 
terpenuhi, baik uji normalitas maupun uji homogenitas. Berdasarkan uji normalitas dan uji homogenitas diketahui bahwa data berdistribusi normal dan homogen, maka selanjutnya dilakukan uji gain score. Hasil uji Gain Score dapat dilihat pada Tabel 2 berikut.

Tabel 2: Hasil Uji Gain Score

\begin{tabular}{cccc}
\hline \multirow{2}{*}{ Kelompok } & \multicolumn{2}{c}{ Rata-rata } & \multirow{2}{*}{ N-Gain } \\
\cline { 2 - 3 } & Tes Awal & Tes Akhir & \\
\hline Kelas Eksperimen & 60,65 & 76,12 & 0,39 \\
Kelas Kontrol & 55,33 & 68,33 & 0,29 \\
\hline
\end{tabular}

Berdasarkan Tabel 2 dapat diketahui bahwa hasil N-gain pada kelas eksperimen adalah 0,39 dan $\mathrm{N}$-gain pada kelas kontrol adalah 0,29. Klasifikasi $\mathrm{N}$-Gain adalah $\mathrm{g}<0,30=$ rendah, $030<\mathrm{g}>0,70=$ sedang, $\mathrm{g}>$ $0,70=$ tinggi. Hasil $\mathrm{N}$-gain kelas eksperimen adalah 0,39 sehingga termasuk dalam kategori sedang. N-gain pada kelas kontrol sebesar 0,29 sehingga termasuk kategori rendah. Berdasarkan hasil uji gain dapat disimpulkan bahwa selisih kelas eksperimen lebih tinggi dari kelas kontrol sehingga dapat disimpulkan bahwa pembelajaran pada kelas eksperimen lebih baik dari kelas kontrol.

Untuk membuktikan uji perbedaan hasil belajar siswa materi bangun ruang dengan menggunakan uji-t. Dalam uji-t, ada beberapa ketentuan yang harus dijadikan pedoman. Ketentuan tersebut yaitu jika $t_{\text {hitung }}<t_{\text {tabel }}$ atau nilai signifikansi $>0,05$, maka h0 diterima, dan jika $t_{\text {hitung }}$ $>t_{\text {tabel }}$ atau nilai signifikansi $<0,05$, maka h0 ditolak. Dalam penelitian ini, peneliti menggunakan sampel sebanyak 61 orang, maka nilai derajat kebebasan $(\mathrm{dk})=\mathrm{n}-2=69-2=59$ dan taraf kesalahan $5 \%$ untuk uji 2 pihak maka dapat diketahui nilai $=2,001$ (Priyatno, 2010: 113). Hasil penghitungan uji hipotesis dengan menggunakan program SPSS versi 23 hasil independent sample $t$ test dapat dilihat pada Tabel 3.

Tabel 3: Hasil Independent Sample t Test

t-test for Equality of Means 


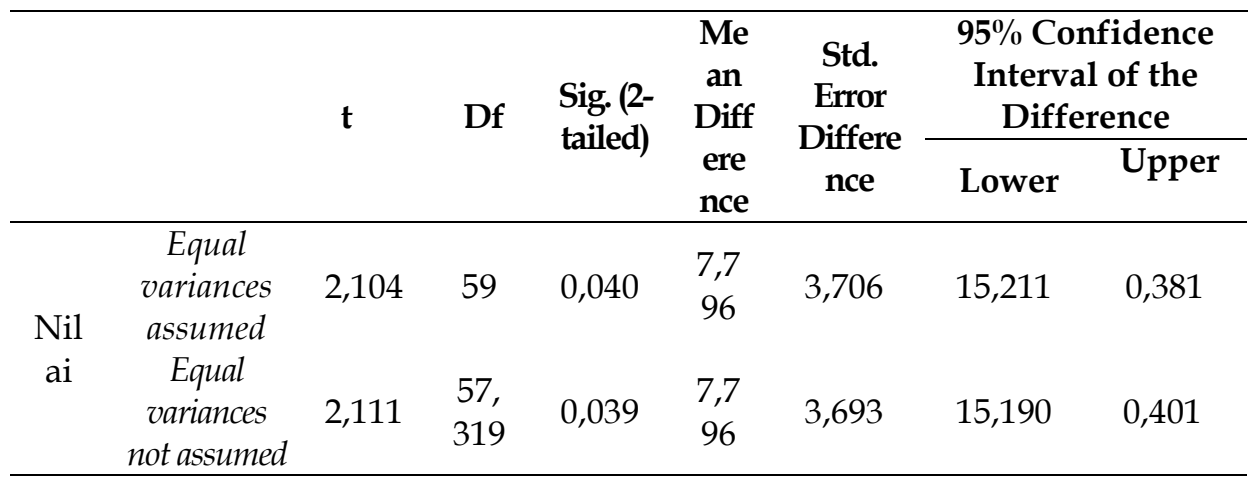

Berdasarkan Tabel 3 diketahui bahwa data dalam penelitian adalah homogen, maka untuk mengetahui hasil uji hipotesis dapat dilihat pada kolom equal variances assumed. Jika tidak homogen, untuk mengetahui hasil uji hipotesis dapat dilihat pada kolom equal variances not assumed. Berdasarkan hasil penghitungan dengan SPSS versi 23 kolom equal variances assumed dapat diketahui bahwa nilai $t_{\text {hitung }}=2,104$ dan signifikansinya sebesar 0,040. Dari hasil penghitungan tersebut dapat diketahui bahwa 2,104 $>2,001$ atau $t_{\text {hitung }}>t_{\text {tabel }}$ dan 0,040 $<0,05$ atau nilai signifikansi $<0,05$. Berdasarkan ketentuan yang berlaku untuk pengujian hipotesis yang telah peneliti paparkan di atas, maka H0 ditolak. Jadi, kesimpulan dari penelitian ini yaitu ada perbedaan hasil belajar materi bangun ruang antara siswa pada kelas kontrol tanpa penerapan model pembelajaran Two Stay Two Stray dan kelas eksperimen dengan penerapan model pembelajaran Two Stay Two Stray.

Hasil uji regresi linier pengaruh model pembelajaran Two Stay Two Stray terhadap hasil belajar siswa materi bangun ruang pada kelas eksperimen dapat dilihat pada Tabel 4.

Tabel 4: Hasil Uji Regresi Linier Pengaruh Model Pembelajaran Two Stay Two Stray terhadap Hasil Belajar Siswa

\begin{tabular}{lccccc}
\hline Model & \multicolumn{4}{c}{ Coefficients $^{\mathbf{a}}$} & \\
\hline & $\begin{array}{c}\text { Unstandardized } \\
\text { Coefficients }\end{array}$ & $\begin{array}{c}\text { Standardized } \\
\text { Coefficients }\end{array}$ & t & Sig. \\
\cline { 2 - 4 } & B & Std. Error & Beta & & \\
\hline
\end{tabular}




\begin{tabular}{ccccccc}
\hline \multirow{2}{*}{1} & (Constant) & 9,050 & 3,953 & & 2,289 & 0,030 \\
\cline { 2 - 5 } & $\begin{array}{c}\text { Model Two Stay } \\
\text { Two Stray }\end{array}$ & 0,787 & 0,051 & 0,945 & 15,298 & 0,000 \\
\hline
\end{tabular}

a. Dependent Variable: Materi Bangun Ruang

Dari Tabel 4 diketahui bahwa uji regresi kelas eksperimen diperoleh hasil sebesar 15,298 dengan signifikansi 0,000. Dari hasil penghitungan tersebut dapat diketahui bahwa 0,000 $<0,005$. Jadi, terdapat pengaruh model pembelajaran Two Stay Two Stray terhadap hasil belajar siswa materi bangun ruang. Untuk melihat nilai kontribusi atau pengaruh X terhadap Y, dapat dilihat output pada Model Summary yaitu nilai $R$ Square (Sukestiyarno, 2011: 120). Hasil uji $R$ Square antara model pembelajaran Two Stay Two Stray terhadap hasil belajar siswa materi bangun ruang pada kelas eksperimen dapat dilihat pada Tabel 5 .

Tabel 5: Hasil Uji R Square antara Model Pembelajaran Two Stay Two Stray terhadap Hasil Belajar Siswa

\begin{tabular}{lcccc}
\hline \multicolumn{5}{c}{ Model Summary } \\
\hline Model & R & R Square & $\begin{array}{c}\text { Adjusted R } \\
\text { Square }\end{array}$ & $\begin{array}{c}\text { Std. Error of the } \\
\text { Estimate }\end{array}$ \\
\hline 1 & $0,945^{\mathrm{a}}$ & 0,893 & 0,889 & 4,28737 \\
\hline a. & Predictors: (Constant), Two Stay Two Stray & \\
b. & Dependent Variable: Materi Bangun Ruang & \\
\hline
\end{tabular}

Dari Tabel 5 dapat diketahui bahwa hasil uji determinasi nilai $R$ Square sebesar 0,893 . Hal ini berarti bahwa $89,3 \%$ variasi besarnya variabel hasil belajar siswa materi bangun ruang bisa dijelaskan oleh variasi variabel model pembelajaran Two Stay Two Stray, sedangkan sisanya, sebesar 10,7\% merupakan pengaruh lain di luar model penelitian.

Pengaruh pembelajaran menggunakan model Two Stay Two Stray terhadap hasil belajar siswa dengan materi bangun ruang dianalisis dengan menggunakan uji regresi linear. Untuk menentukan pengaruh penggunaan model Two Stay Two Stray terhadap hasil belajar siswa materi bangun ruang diambil data dari kelas kontrol dan kelas eksperimen. Kelas kontrol mendapat perlakuan model pembelajaran konvensional yaitu siswa 
kelas IIA, sedangkan kelas eksperimen mendapat perlakuan model pembelajaran Two Stay Two Stray yaitu siswa kelas IIB pada SD 1 Barongan. Berdasarkan hasil analisis regresi linear tersebut diperoleh informasi bahwa pembelajaran dengan menggunakan model Two Stay Two Stray bepengaruh secara positif terhadap hasil belajar siswa bangun ruang.

Data hasil belajar siswa materi bangun ruang dengan penerapan model pembelajaran Two Stay Two Stray antara kelas eksperimen dan kelas kontrol dapat dilihat pada Gambar 1.

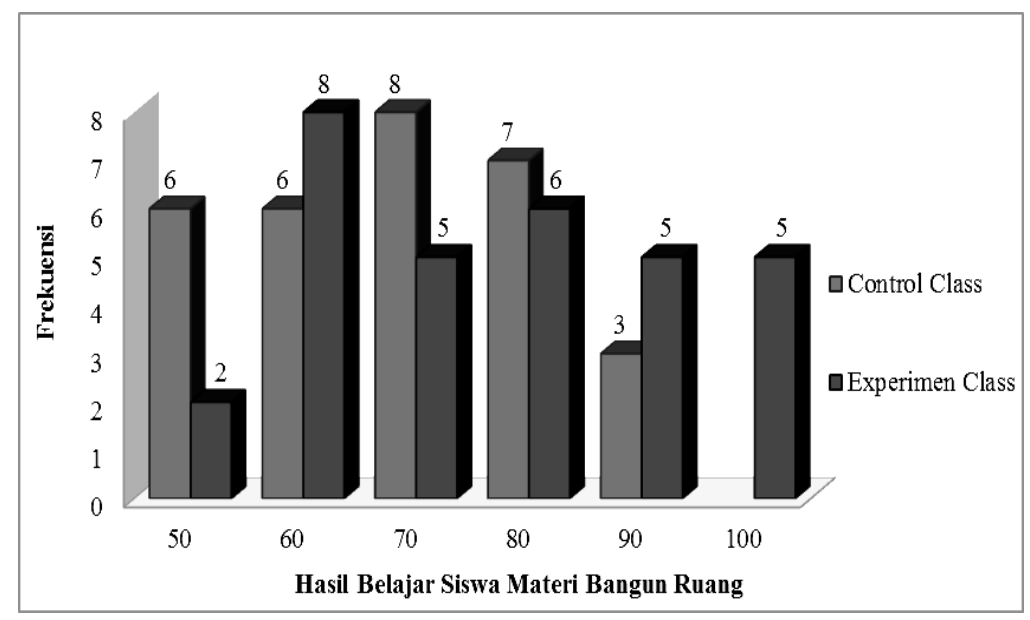

\section{Pembahasan}

Data hasil belajar siswa materi bangun ruang antara kelas eksperimen dan kelas kontrol menunjukkan adanya perbedaan yang signifikan. Perlakuan (treatment) dengan penerapan model pembelajaran Two Stay Two Stray menghasilkan data yang berbeda pada kedua kelas tersebut. Hal ini diperkuat penelitian dari Mahyuni, dkk. (2014) yang menyatakan bahwa model pembelajaran Two Stay Two Stray dapat meningkatkan prestasi belajar siswa. Hal tersebut dibuktikan dengan hasil $t_{\text {hitung }}$ lebih besar $t_{\text {tabel }}$ yaitu sebesar 6,336 $>2,000$ dengan perolehan nilai rata-rata hasil belajar kelas eksperimen lebih dari pada kelas kontrol yaitu sebesar 78,50 > 70,58. Jadi, dapat disimpulkan bahwa model pembelajaran Two Stay Two Stray dapat meningkatkan hasil belajar IPA. 
Pembelajaran kooperatif struktur Two Stay Two Stray mempunyai perbedaan dengan pembelajaran kooperatif lainnya yaitu menyediakan kesempatan untuk menyerahkan pekerjaan atau informasi kepada kelompok lain (Sulisworo dan Suryani, 2014). Kegiatan berbagi membiasakan siswa untuk menghormati setiap pendapat dari kelompok lain. Siswa dapat belajar untuk mengekspresikan diri mereka terhadap pendapat orang lain. Pengakuan opini dari siswa lain dapat meningkatkan rasa percaya diri dan memotivasi siswa untuk mengekspresikan ide-ide atau pendapat mereka. Hal ini tampak pada hasil belajar siswa materi bangun ruang setelah diberikan perlakuan pada Gambar 1.

Data penelitian ini menunjukkan pembelajaran dengan model pembelajaran Two Stay Two Stray lebih efektif dari pada hasil belajar siswa dengan penerapan model konvensional. Pembelajaran yang efektif merupakan pembelajaran yang menumbuhkan minat dan motivasi siswa sehingga tujuan pembelajaran tercapai. Hal ini sesuai dengan pernyataan Megayani dan Ilmi (2017) bahwa penggunaan model pembelajaran kooperatif tipe Two Stay Two Stray terbukti telah membantu kegiatan pembelajaran peserta didik menjadi lebih menarik dan menyenangkan sehingga dapat menumbuhkan minat dan motivasi dalam belajar peserta didik serta membuat peserta didik menjadi interaktif dan komunikatif.

Model pembelajaran Two Stay Two Stray melibatkan siswa aktif dan antusias pada saat mengikuti pembelajaran. Hal ini sesuai dengan pendapat Ovibella, dkk. (2020) yang menyatakan bahwa model TSTS ini memberikan kesempatan bagi siswa untuk mengekspresikan pendapat mereka dan dapat berinteraksi serta berdiskusi dengan kelompok lain sehingga pembelajaran tidak hanya terpusat pada guru, sehingga siswa menikmati pembelajaran dan tidak merasa bosan mengikuti pelajaran. Kegiatan pada pembelajaran yang menerapkan model pembelajaran Two Stay Two Stray mampu membuat siswa lebih aktif, kritis, dan bekerja sama dengan temannya untuk menyelesaikan tugas dengan baik sehingga tujuan pembelajaran dapat tercapai. Tujuan pembelajaran matematika 
adalah untuk membekali mereka dengan kemampuan berpikir logis, analitis, sistematis, kritis, dan kreatif serta memiliki kemampuan untuk bekerja sama (Daryanto dan Raharjo, 2012: 240).

Model pembelajaran Two Stay Two Stray mudah diterapkan dan sesuai dengan karakteristik siswa SD. Langkah-langkah pelaksanaan model pembelajaran Two Stay Two Stray memungkinkan siswa untuk aktif bergerak dan berpindah-pindah. Model Two Stay Two Stray menuntut siswa untuk berpindah dari satu kelompok ke kelompok yang lain dengan jangka waktu yang sedikit. Kegiatan yang dilakukan pada pembelajaran yang menerapkan model pembelajaran Two Stay Two Stray menjadikan siswa aktif dalam belajar sehingga berdampak pada meningkatnya hasil belajar siswa. Septimarmisa, dkk. (2018) menyatakan bahwa model pembelajaran TSTS melibatkan peran aktif siswa dalam pembelajaran sehingga siswa dapat berpikir kritis dan analitis untuk mencari dan menemukan jawaban atas masalah dalam pertanyaan.

Model pembelajaran Two Stay Two Stray tidak hanya mengaktifkan siswa, tetapi juga memberikan hasil yang optimal. Model ini menuntut siswa untuk berpindah atau aktif berkomunikasi bertukar informasi mengenai materi yang dipelajari, membuat masing-masing siswa memiliki tanggung jawab menyampaikan materi yang dipelajari dan yang mendengarkan akan mencatat dan memahami apa yang disampaikan oleh temannya yang lain untuk selanjutnya dipresentasikan di depan kelas (Rhiantini dkk., 2017). Oleh sebab itu, pembelajaran yang baik haruslah mengaktifkan siswa, memberikan kesempatan kepada siswa untuk berinteraksi dan berbagi pengetahuan serta melatih siswa untuk membangun dan menemukan pengetahuannya sendiri.

\section{Penutup}

Penelitian membuktikan bahwa hasil belajar siswa pada kelas yang menerapkan model pembelajaran Two Stay Two Stray lebih tinggi daripada pembelajaran dengan cara konvensional. Model pembelajaran 
Two Stay Two Stray berpengaruh terhadap hasil belajar matematika siswa kelas II di SD 1 Barongan materi bangun ruang.

Sebelum menerapkan model Two Stay Two Stray, guru hendaknya merencanakan pembelajaran yang akan dilaksanakan, terutama hal-hal yang berkaitan dengan model Two Stay Two Stray seperti: pembagian kelompok yang terdiri dari siswa yang memiliki kemampuan heterogen. Sebelum melaksanakan pembelajaran, guru perlu menyampaikan langkah-langkah pelaksanaan model Two Stay Two Stray dengan jelas sehingga siswa dapat mengikuti pembelajaran dengan lancar. Manajemen waktu perlu dipertimbangkan dengan matang karena model Two Stay Two Stray memerlukan waktu yang lama. Selain itu, guru juga diharapkan dapat melakukan variasi model pembelajaran Two Stay Two Stray dengan model lainnya sehingga diperoleh model yang lebih sesuai dengan karakteristik pokok bahasan dan kondisi siswa.

\section{Ucapan Terima Kasih}

Penelitian ini dapat diselesaikan berkat bantuan dari berbagai pihak. Oleh karena itu, peneliti menyampaikan ucapan terima kasih dan penghargaan setinggi-tingginya kepada pihak yang telah membantu penyelesaian penelitian ini. Ucapan terima kasih peneliti sampaikan pertama kali kepada Kepala SD 1 Barongan Bpk. Maskat, S.Pd. serta Bapak/Ibu guru SD 1 Barongan. Tidak lupa juga untuk istriku, Tyesa Resti Rosavina, S.Pd. SD., M.Pd., yang selalu memotivasi dan memberikan dukungan sehingga peneliti dapat menyelesaikannya penelitian ini.

\section{Daftar Referensi}

Abtahi, M., \& Battell, C. (2017). Integrate Social Justice Into the Mathematics Curriculum in Learning. Jurnal Ilmiah Peuradeun, 5(1), 101-114. doi:10.26811/peuradeun.v5i1.123

Anim, A., Prasetyo, Y., \& Rahmadani, E. (2019). Experimentation of Problem Posing Learning Model Assisted of Autograph Software 
to Students' Mathematical Communication Ability in Terms of Student's Gender. Jurnal Ilmiah Peuradeun, 7(2), 331-342. doi:10.26811/peuradeun.v7i2.301

Arthaningsih, N. K. J., \& Diputra, K. S. (2019). Pengaruh Model Pembelajaran Kooperatif Tipe Two Stay Two Stray Melalui Lesson Study terhadap Hasil Belajar Matematika. Journal of Education Technology, 2(4), 128-136. doi:10.23887/jet.v2i4.16424.

Bagas. D. A., Imam S., \& Rubon. S. (2018). Penerapan Model Pembelajaran Kooperatif Tipe Two Stay - Two Stray (TSTS) dalam Meningkatkan Kemampuan Pemecahan Masalah Matematika Materi Geometri pada Siswa Kelas VIII-G SMP Negeri 1 Surakarta Tahun Pelajaran 2016/2017. Jurnal Pendidikan Matematika dan Matematika (JPMM) Solusi, 2 (3), 205-209. doi:10.20961/jpmm\%20solusi.v2i3.20680.

Daryanto \& Raharjo, M. (2012). Model Pembelajaran Inovatif. Yogyakarta: Gava Media.

Desmita. (2014). Psikologi Perkembangan Peserta Didik. Bandung: Remaja Rosdakarya.

Fahmi, C., AR, M., Nurliza, E., \& Usman, N. (2019). The Implementation of Academic Supervision in Improving Teacher Competency at Primary School. Jurnal Ilmiah Peuradeun, 7(1), 181-194. doi:10.26811/peuradeun.v7i1.202

Fonna, M., \& Mursalin, M. (2018). Role of Self-Efficacy Toward Students' Achievement in Mathematical Multiple Representation Ability (MMRA). Jurnal Ilmiah Peuradeun, 6(1), 31-40. doi:10.26811/peuradeun.v6i1.174

Hamruni. (2012). Strategi Pembelajaran. Yogyakarta: Insan Madani.

Huda, M. (2017). Model-Model Pengajaran dan Pembelajaran Isu-Isu Metodis dan Pragmatis. Yogyakarta: Pustaka Pelajar.

Mahyuni, K. A., Meter, I. G., \& Suara, I. M. (2014). Pengaruh Model Pembelajaran Kooperatif Tipe Two Stay Two Stray (TSTS) terhadap Prestasi Belajar IPA Siswa Kelas V SD Negeri 8 Padangsambian Kecamatan Denpasar Barat Tahun Ajaran 2013/2014. e-Jurnal Mimbar PGSD Universitas Pendidikan Ganesha Jurusan PGSD, 2(1). doi:10.23887/jjpgsd.v2i1.4416.

Megayani \& Ilmi, M. (2017). Penerapan Model Pembelajaran Kooperatif Tipe Two Stay Two Stray (TSTS) terhadap Hasil Belajar Siswa pada Materi 
Wahyul Huda

Sistem Ekskresi. Journal Bio Educatio, 2(2), 27-34. doi:10.31949/be.v2i2.760.

Ovibella. R., Sri. H., \& Eko. H. (2020). The Effectiveness of the Two Stay Two Stray Model using Pocket Number Media in Social Sciences Subjects. Journal of Primary Education, 9(3), 328-333. doi:10.15294/jpe.v9i3.33683.

Priyatno, D. (2010). Paham Analisa Statistik Data dengan SPSS. Yogyakarta: MediaKom.

Rhiantini, S., Sunarya, D. T., \& Iswara, P. D. (2017). Penerapan Metode Two Stay Two Stray dalam Upaya Meningkatkan Keterampilan Menulis pada Materi Laporan Pengamatan. Jurnal Pena Ilmiah, 2(1), 121-130. doi:10.23819/jpi.v2i1.9533.

Septimarmisa, C., Syamsurizal, \& Lufri. (2018). The influence of two stay two stray learning model nuanced by scientific literacy on students' learning competence in smpn 4 kerinci. International Journal of Progressive Sciences and Technologies, 8(1), 89-95. doi:10.47494/ijpst.v8.1.393.

Siswanto, R., Sugiono, S., \& Prasojo, L. (2018). The Development of Management Model Program of Vocational School Teacher Partnership with Business World and Industry Word (DUDI). Jurnal Ilmiah Peuradeun, 6(3), 365-384. doi:10.26811/ peuradeun.v6i3.322

Sukestiyarno, Y. L. (2011). Statistika Dasar. Semarang: Unnes.

Sulisworo, D., \& Suryani, F. (2014). The effect of cooperative learning, motivation and information technology literacy to achievement. International Journal of Learning $\mathcal{E}$ Development, 4(2), 58-64. Doi:10.5296/ijld.v4i2.

Susanto, A. (2015). Teori Belajar dan Pembelajaran di Sekolah Dasar. Jakarta: Prenadamedia Group.

Vitoria, L., \& Monawati, M. (2016). Improving Students' Problem Solving Skill in Mathematics Through Writing. Jurnal Ilmiah Peuradeun, 4(2), 231-238. doi:10.26811/peuradeun.v4i2.100 
Vol. 5, No. 2, Juli 2021 